\title{
Musculoskeletal Pain and Work-related Risk Factors among Waste Collectors in Hanoi, Vietnam: A Cross-sectional Study
}

\author{
Bang Van Nguyen ${ }^{1}$, Thuy Thi Thu Tran ${ }^{2 *}$, Ngan Thi Hoang $^{3}$, Bich Ngoc Nguyen ${ }^{4}$, Quynh Thuy Nguyen ${ }^{5}$ \\ ${ }^{1}$ Department of Haematology, Toxicology, Radiation and Occupational Diseases, Military Hospital 103, Vietnam Military Medical \\ University, Hanoi, Vietnam; ${ }^{2}$ Department of Occupational Health and Safety, Hanoi University of Public Health, Hanoi, Vietnam; \\ ${ }^{3}$ Department of Sales, Daiichi Life Insurance of Vietnam Company, Hanoi, Vietnam; ${ }^{4}$ Department of Occupational Health and \\ Safety, Hanoi University of Public Health, Hanoi, Vietnam; ${ }^{5}$ Department of Occupational Health and Safety, Hanoi University of \\ Public Health, Hanoi, Vietnam
}

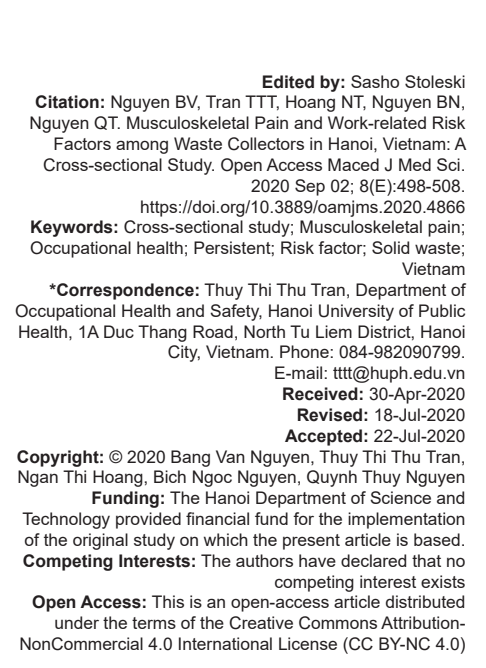

\begin{abstract}
BACKGROUND: Musculoskeletal disorders (MSDs) are prevalent among waste collectors (WCs) in developing countries.

AIM: This study aimed to investigate the prevalence of MSDs and the factors associated with the risk of persistent musculoskeletal pain among WCs in Hanoi, Vietnam.

METHODS: A cross-sectional survey was utilized to study 468 WCs in 2017. The Örebro Musculoskeletal Pain Questionnaire and a questionnaire on demographic and work conditions were used to collect data. Descriptive and multivariate logistics regression analyzes were applied at a significance level of 0.05 to examine the factors related to the risk of persistent pain.

FINDINGS: About $74.4 \%$ of the participants of this study experienced MSDs in at least one body region and $9.4 \%$ reported MSDs in all 10 body sites. The lower back was reported to be the most affected followed by the neck and shoulders. The risk of persistent musculoskeletal pain was significantly associated with age (odds ratio $(O R)=2.31$ confidence interval $(\mathrm{Cl})=1.05-5.09)$, gender $(\mathrm{OR}=3.29, \mathrm{Cl}=1.28-8.44)$, work hours $(\mathrm{OR}=2.35, \mathrm{Cl}=1.12-4.92)$, work shift $(\mathrm{OR}=0.48, \mathrm{Cl}=0.26-0.92)$, duration of poor postures of the neck $(\mathrm{OR}=0.31, \mathrm{Cl}=0.13-0.76)$, bent back $(\mathrm{OR}=0.4 \mathrm{Cl}=0.18-0.92)$ and for medial rotation $(\mathrm{OR}=3.01, \mathrm{Cl}=1.42-6.36)$, carrying heavy objects $(\mathrm{OR}=2.94, \mathrm{Cl}=1.15-7.48)$, and experience of work dissatisfaction $(\mathrm{OR}=3.31, \mathrm{Cl}=1.46-7.52)$, stress $(\mathrm{OR}=7.14, \mathrm{Cl}=3.14-16.24)$, or anxiety $(\mathrm{OR}=6.37, \mathrm{Cl}=3.07-13.21)$

CONCLUSIONS: High prevalence of MSDs among WCs and its association with self-assessed unfavorable work postures and work-related stress implies the need of mechanical and social support at work for WC to prevent the
\end{abstract} development of MSDs and persistent pain.

\section{Introduction}

Work-related musculoskeletal disorders (MSDs), consist of a wide range of degenerative and inflammatory conditions, affect the supporting blood vessels, peripheral nerves, joints, ligaments, tendons, and muscles. MSDs are the leading cause of disability [1], [2] among workers impairing body functions, reducing work capabilities, and affecting the quality of life [3], eventually causing significant economic ramifications to the workers [4]. Although a high prevalence of MSDs has been reported in various occupations [5], [6], [7], [8], [9], [10], [11], many employees have to keep working even with pain and discomfort for the income. Hence, these workers are continuously being exposed to a specific occupational hazard, further aggravating their pain conditions and inflicting persistent pain in the musculoskeletal system. However, the factors influencing persistent musculoskeletal pain are still unclear and understanding these factors is significant to develop effective prevention and control measures. In addition, most studies on chronic MSDs focused on patients (i.e., participants who are already injured or who have left work because of long-term musculoskeletal pain) [12], [13], [14], [15], [16] or the general population [17], while only a few studies have mentioned the persistence of musculoskeletal pain and disability in the workforce [3], [15], [18] and no study has reported on the potential risk of persistent musculoskeletal pain and associated factors for waste collectors (WCs) in Vietnam.

WCs are particularly susceptible to work-related MSDs, especially in developing countries [9], [19], [20], [21], [22]. With limited resources, inadequate work equipment, and poor labor conditions, WCs collect municipal waste manually in daily routine. They frequently perform intense physical activities such as carrying, pushing, pulling, or lifting heavy objects for long working hours [9], [19], [23], [24]. These movements if done wrongly and with bad postures may inflict serious strain on workers' musculoskeletal 
system [9], [19], [24]. The collection process is mainly done outdoor and on the streets without access to adequate shelters for temporary rest, thus WCs are directly affected by changes in climatic conditions such as temperature, humidity, and sunlight [19], [23], [25], [26]. Aside from the physical hazards of manual labor, WCs are also at high risk of psychological stress [27], which is associated with the development of MSDs [28]. In addition, individual factors such as age, gender, and body mass index can contribute to the elevated risk of MSDs among workers in general [3], [21], [22], [29]. Continuous exposure to a variety of risk factors can stimulate the transition from acute to chronic MSDs among WCs, leading to long-term disability.

Rapid urbanization and high population density in a metropolis such as Hanoi city, the capital of Vietnam, generate huge amounts of solid waste everyday, which is collected manually [30]. The heavy workload coupled with harsh working conditions such as extreme heat in summer and low temperature in winter, in association with lack of mechanical support for manual work put the WCs at high risk of acute and chronic MSDs. However, evidence on the risk of chronic musculoskeletal pain among workers worldwide and particularly among the WCs in Vietnam is scarce. Hence, the present study aimed to assess the prevalence of MSDs and identify the factors associated with the risk of persistent musculoskeletal pain among WCs in Hanoi, Vietnam. To the best of our knowledge, this study is the first attempt to examine the risk of long-term disability due to musculoskeletal pain among WCs. Results of this study can yield many insights for the development of appropriate policies and programs in response to MSDs prevention in WCs, both in Vietnam and other similar settings in the world.

\section{Methods}

\section{Study design and selection of participants}

A cross-sectional study was conducted from January to October 2017. The selection criteria included (1) having a labor contract; (2) being directly involved in the waste collection process; and (3) having 18 months of work experience by the time of recruitment. All eligible WCs (488) from a branch of an urban environmental company in Hanoi, Vietnam, were invited to partake in the study. However, nine WCs were not included because they were not present at their worksite during the interview and 11 questionnaires with missing data were removed. The final sample size was 468 WCs (response rate of $95.9 \%$ ).

\section{Data collection}

Initially, the personnel department of the company was contacted to obtain permission and acquire the list of eligible WCs. Then, the study was introduced to the WCs at their worksites, and participants were invited to join with the assistance of the WCs team leaders. Each worksite was conveniently visited 3 times within 1 month to interview as many WCs as possible. In case, the WCs were not present at the worksite during all visits due to any reasons (e.g., sick leave and work absence), they were excluded from the survey. Interviews were conducted after or before the work shift. Participating WCs were requested to sign a consent form before the interview. Since WCs worked simultaneously, the original self-administrated method [16] was not possible. Hence, the questions were read aloud, and responses were recorded by data collectors instead.

The survey questionnaires had two parts: Demographic and work characteristics and the Örebro Musculoskeletal Pain Questionnaire (ÖMPQ), which are presented in Appendix 1.

\section{Measures \\ Prevalence of MSDs and multisite MSDs and Risk of persistent MSDs based on the ÖMPQ}

The ÖMPQ was utilized to identify the body sites with MSDs and to assess the impacts of persistent MSDs on various body functions, daily activities, and work performance [12], [13], [14], [15], [16]. In this study, the English version of ÖMPQ was translated, piloted, and revised before the actual survey, as presented in Appendix 1. The Cronbach's alpha of the Vietnamese ÖMPQ was 0.76 , which indicated acceptable reliability [31]. The first four questions (Part A) were about the personal information of the WCs. The next 21 questions (Q5 to Q25) covered the different aspects of MSDs (i.e., prevalence, duration, and effect of experienced MSDs) [16] and thus contributed to the total ÖMPQ score. Q5 to Q7 indicated the body regions with pain, the duration of the concerned pain, and the number of workdays lost because of pain during the past 18 months. Q8 and Q17 measured the workers' perception of their working conditions. Q9 to Q12 examined the participant's self-evaluation of pain and coping strategies. Q13 to Q16 addressed the participants' psychological state, the risk of their pain becoming persistent, and the ability to work in the next 6 months. Q18 to Q20 evaluated how much physical activities affected the workers' pain. The final five questions, from Q21 to Q25, described workers' ability to participate in daily activities with current pain condition [16].

The prevalence of MSDs was calculated from the WCs who reported pain in at least one body region based on ÖMPQ, Q5, "Where do you have pain?" The list of body regions included was the neck, the shoulder, the arm, the upper back, the lower back, and the leg but was not limited to these six areas. The multisite MSDs, 
on the other hand, were considered if MSD pain in at least two body sites (ÖMPQ, Q5) were reported.

The risk of persistent MSDs was evaluated based on the total ÖMPQ score. The total ÖMPQ score was the sum of the score per question with different weight. Q5 score was the product of two and the number of reported pain sites, but should not exceed 10. The scores of Q6 and Q7 were the bracketed numbers after the ticked boxes of the answers. For Q8, Q9, Q10, Q11, Q13, Q14, Q15, Q18, Q19, and Q20, the score was the number that has been selected as an answer. For Q12, Q16, Q17, Q21, Q22, Q23, Q24, and Q25, the score was calculated by subtracting the circled number by 10 [16]. Originally, a cutoff score of $<105$ indicated a low risk of persistent MSDs, then a score from 105 to 130 meant moderate risk and a score of $>130$ signified high risk [16]. However, the prediction of chronicity varied from 90 to 105 [14], in which a lower score could lead to increased true positives (possibly including more participants at risk) while a higher score could result in reduced false positives (limiting to participants who were truly at risk) [14]. Therefore, a cutoff point of 105 was used to categorize participants into low-risk group (score <105) and moderate to high-risk group (score $\geq 105$ ).

The definition of persistence or chronicity of MSD or pain in empirical literature is inconsistent [2]. Several studies reported persistent pain based on the duration of pain which ranged from weeks to months [17], even years, or decades [32]. A number of studies have defined persistent musculoskeletal pain as having pain for 3 months or less [3], [17], [33] or 6 months [18], [34]. In this study, the total ÖMPQ score was the only indicator to determine the risk of pain chronicity [16].

\section{Demographic and work characteristics}

Two groups of factors were collected and analyzed for their potential relationships with the risk of chronic pain, namely, the demographics and the work conditions.

The demographic information of individual WCs included age, gender, education level, and the number of years working as WC (work seniority). Age and work seniority were categorized into two groups (>39 vs. $\leq 39$ years old and $\geq 15$ vs. $<15$ working years, respectively). Gender included male and female groups and education level was classified into two groups, namely, primary to high school and above high school.

Work characteristics were divided into four groups of variables, namely, work organization, exposure to physical occupational hazards, selfreported unfavorable work postures, and psychological stress at work. Work organization variables included the number of work hours per shift ( $\leq 8 \mathrm{vs.} \mathrm{9-12} \mathrm{hours/shift)}$ and work shift in the past 3 months (Shift 3 from 6 p.m. to 2 a.m. and others including Shift 1 from 5 a.m. to 1 p.m., Shift 2 from 1 p.m. to 8 p.m., and frequently changed shift). Physical occupational hazards focused on the frequency of exposure to sunlight, hot/cold/wet weather conditions (frequent exposure vs. seasonal to none exposure). Unfavorable working postures were expressed by time spent performing 12 specific postures which were common among WCs ( $\geq 2$ vs. $<2$ hours per shift, illustration in Appendix 1). The experience of psychological stress at work included level of anxiety and stress during the previous week (high vs. acceptable), level of satisfaction about work conditions during the previous week (unsatisfied vs. acceptable), and exposure to the threat of physical and psychological violence at work (yes vs. never).

\section{Statistical analysis}

The collected data were analyzed using SPSS Version 22.0. Descriptive analysis was done to assess the mean Örebro score, the prevalence and body site of MSDs, and risk of persistent musculoskeletal pain. To investigate the factors associated with the risk of persistent musculoskeletal pain, two groups, the low risk (Örebro score <105) and the moderate to high risk of persistent musculoskeletal pain (Örebro score $\geq 105$ ), were assigned as the dependent variables, while the demographic characteristics and working conditions were the independent variables (covariates). Specifically, the (1) personal and work organization variables; (2) exposure to occupational hazards; (3) duration performing unfavorable working postures; and (4) experience of psychological stress at work were used as covariates. The association between covariates and the risk of chronic musculoskeletal pain was examined using multivariate logistics regression (Enter method, a significance level of 0.05). Odds ratios (OR), 95\% confidence interval $(\mathrm{Cl})$, and significance levels $(p)$ were reported.

\section{Ethics approval and consent to participate}

The study was approved by the ethics committee for biomedical research at the Hanoi University of Public Health, Hanoi, under Decision No. 46/2017/YTCC-HDD3, dated 15/02/2017. The participation in the study was completely voluntary and written consent forms were obtained on data collection.

\section{Results}

Table 1 presents the personal information of the study participants. The mean age of participants was 38.3 (SD = 7.7). Majority of the WCs were female $(83.1 \%)$ and were able to complete primary to high school education (95.5\%). One-third of WCs had been working as WCs for more than 15 years (31.8\%). More 
than $80 \%$ of the participants worked for 8 hours per shift, and most of them took the night shift from 6 p.m. to 2 a.m. in the past 3 months $(75.2 \%)$.

Table 1: Characteristics of waste collectors who participated in this study $(n=468)$

\begin{tabular}{llll}
\hline Variables & Group & $\mathrm{n}$ & $\%$ \\
\hline Age & $>39$ years old & 198 & 42.3 \\
& $\leq 39$ years old & 270 & 57.7 \\
Gender & Female & 389 & 83.1 \\
& Male & 79 & 16.9 \\
Education level & Primary + high school & 447 & 95.5 \\
& Above high school & 21 & 4.5 \\
Work seniority & $\geq 15$ years & 149 & 31.8 \\
& <15 years & 319 & 68.2 \\
Working hours/shift & $9-12$ hours & 66 & 14.1 \\
\multirow{2}{*}{ Working shift during the past 3 months } & $\leq 8$ hours & 402 & 85.9 \\
& Shift 3 (6 p.m.-2 p.m.) & 352 & 75.2 \\
& Others & 116 & 24.8 \\
\hline
\end{tabular}

\section{The prevalence of musculoskeletal pain}

Among the participants, 348 experienced experiencing pain in at least one body region $(74.4 \%)$ (Table 2). The prevalence of musculoskeletal pain at the lower back was the highest $(62.9 \%)$, followed by pain on the neck $(59.1 \%)$, shoulders (56.9\%), and forearms $(56 \%)$ (Figure 1). Further, $13.9 \%$ of the WCs had pain in only one body site, while $60.5 \%$ experienced pain in several studied body sites.

Table 2: Risk of persistent MSDs among the study participants $(n=468)$

\begin{tabular}{llll}
\hline Variables & Group & $\mathrm{n}$ & $\%$ \\
\hline Presence of musculoskeletal pain by body site (ÖMPQ & No & 120 & 25.6 \\
Q5) & 1 body site & 65 & 13.9 \\
& 2-9 body sites & 239 & 51.1 \\
& 10 body sites & 44 & 9.4 \\
Number of workdays lost because of current pain in & No day lost & 174 & 50.0 \\
the past 18 months (ÖMPQ, Q6) $\mathrm{n}=348$ & $1-2$ days & 87 & 25.0 \\
& $3-7$ days & 55 & 15.8 \\
Duration of current pain problem (ÖMPQ, Q7) $\mathrm{n}=348$ & $\geq 7$ days & 32 & 9.2 \\
& $<3$ months & 58 & 16.7 \\
& $3-12$ months & 56 & 16.1 \\
Orebro score (Mean $\pm \mathrm{SD}=68.9 \pm 47.7$, Median=87) & More than 1 year & 234 & 67.2 \\
& $<105$ & 347 & 74.1 \\
& $105-130$ & 98 & 20.9 \\
\hline MSDs: Musculoskeletal disorders, ÖMPQ: Örebro Musculoskeletal Pain Questionnaire. & 23 & 4.9 \\
\hline
\end{tabular}

About $50 \%$ WCs reported work days lost due to musculoskeletal pain in the previous 18 months. More than $80 \%$ of the participants experienced current pain in at least 3 months ( 290 WCs). The Örebro mean score of the whole sample was 68.9 (SD \pm 47.7 ). One-fourth of WCs were exposed to moderate to high risk of persistent musculoskeletal pain (Örebro mean score $\geq 105$ ).

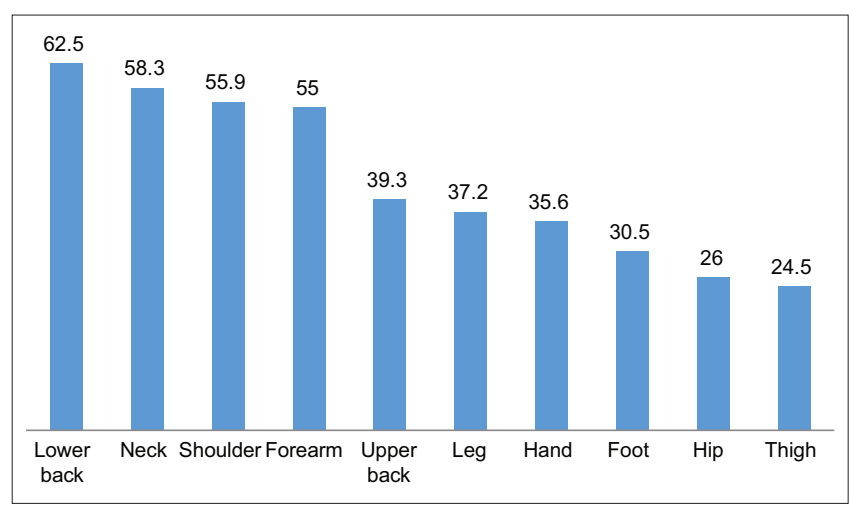

Figure 1: The prevalence of musculoskeletal pain by body site $(n=468)$
MSDs

\section{Factors related to the risk of persistent}

The results in Table 3 showed that WCs with higher risk of musculoskeletal pain were older $(\mathrm{OR}=2.31, \mathrm{Cl}=1.05-0.09)$, female workers $(\mathrm{OR}=3.29$, $\mathrm{Cl}=1.28-8.44)$, worked more than $8 \mathrm{~h} /$ day $(\mathrm{OR}=2.35$, $\mathrm{Cl}=1.12-4.92$ ), and worked at day shift or frequently changed shift $(\mathrm{OR}=0.48, \mathrm{Cl}=0.26-0.92)$. Workers with the neck and the back bent for a prolonged duration at an angle of over $45^{\circ}$ without supportive equipment for more than $2 \mathrm{~h}$ during their shift reported a reduced risk of musculoskeletal pain, compared to those who had these postures $<2 \mathrm{~h}$ ( $\mathrm{OR}=0.31$ and 0.4 , respectively). Longer duration of medial rotation while walking (such as sweeping the street while walking) increased the risk of chronic musculoskeletal pain by 3.01 times among the study participants $(p<0.01)$. Carrying heavy objects with one hand were not a common task since majority of workers only did it for $<2 \mathrm{~h}$ per shift, but this task was significantly associated with the elevated risk of longterm disability $(\mathrm{OR}=2.94, \mathrm{Cl}=1.15-7.48)$. Workers who felt highly anxious, stressed, or unsatisfied with work during the week before the survey also had a significantly higher risk than those who rated these psychological conditions as "acceptable" ( $p<0.01)$.

\section{Discussion}

MSDs were found to be prevalent among the study participants and a considerable number of WCs had moderate to high risk of persistent musculoskeletal pain. The factors that significantly associated with the risk of chronic musculoskeletal pain included age, gender, work hours, work shift, several work postures, and psychological conditions 1 week before the survey.

\section{The prevalence of musculoskeletal pain among WCs}

The percentage of WCs who experienced musculoskeletal pain in at least one body region in this study $(74.4 \%)$ was much higher than those reported in other studies among WCs in low- and middle-income countries with similar settings such as Vietnam, India, or Brazil (44.7-73.5\%) [19], [21], [22], [35] but lower than that of Iranian WCs (92.5\%) [9]. The manual waste collection process involves whole-body movements with the lower back bearing the highest amount of impact [4], [24]. Moreover, waste collecting job requires workers to stay in poor postures such as standing, moving, twisting the body, and sweeping for a long time, which mainly affect the back, legs, and hands, resulting in high MSD prevalence in these body parts. This was confirmed by several studies that MSDs in WCs mostly occurred in the lower back [9], [19], [20], [21], [22], [35], 
Table 3: Associations between demographic, work-related characteristics, and risk of persistent musculoskeletal pain in a multivariate logistics regression $(n=468)$

\begin{tabular}{|c|c|c|c|c|c|c|c|}
\hline \multirow[t]{2}{*}{ Variables $^{a}$} & \multirow{2}{*}{$\begin{array}{l}\text { Group } \\
\text { Total }\end{array}$} & \multirow{2}{*}{$\begin{array}{l}\text { Study sample } \\
468\end{array}$} & \multicolumn{2}{|c|}{$\begin{array}{l}\text { Moderate to high risk } \\
\text { (Orebro } \geq 105)\end{array}$} & \multirow[t]{2}{*}{$\begin{array}{l}\text { Adjusted } \\
\text { OR }\end{array}$} & \multicolumn{2}{|c|}{$95.0 \% \mathrm{Cl}$ for OR } \\
\hline & & & $\frac{n}{121}$ & $\frac{\%}{25.9}$ & & Lower & Upper \\
\hline \multicolumn{8}{|l|}{ Personal and work organization } \\
\hline Age & $\begin{array}{l}>39 \\
\leq 39\end{array}$ & $\begin{array}{l}198 \\
270\end{array}$ & $\begin{array}{l}65 \\
56\end{array}$ & $\begin{array}{l}32.8 \\
20.7\end{array}$ & $2.31^{*}$ & 1.05 & 5.09 \\
\hline Gender & $\begin{array}{l}\text { Female } \\
\text { Male }\end{array}$ & $\begin{array}{l}389 \\
79\end{array}$ & $\begin{array}{l}113 \\
8\end{array}$ & $\begin{array}{l}29.0 \\
10.1\end{array}$ & $3.29^{*}$ & 1.28 & 8.44 \\
\hline Working hours/shift & $\begin{array}{l}9-12 \mathrm{~h} \\
\leq 8 \mathrm{~h}\end{array}$ & $\begin{array}{l}66 \\
402\end{array}$ & $\begin{array}{l}28 \\
93\end{array}$ & $\begin{array}{l}42.4 \\
23.1\end{array}$ & $2.35^{\star}$ & 1.12 & 4.92 \\
\hline Working shift during the past 3 months & $\begin{array}{l}\text { Shift } 3 \text { ( } 6 \text { p.m. }-2 \text { p.m.) } \\
\text { Others }\end{array}$ & $\begin{array}{l}352 \\
116\end{array}$ & $\begin{array}{l}83 \\
38\end{array}$ & $\begin{array}{l}23.6 \\
32.8\end{array}$ & $0.48^{*}$ & 0.26 & 0.92 \\
\hline \multicolumn{8}{|l|}{ Duration performing unfavorable working posture } \\
\hline $\begin{array}{l}\text { The neck bent for a prolonged duration at an angle of over } 45^{\circ} \\
\text { without supportive equipment }\end{array}$ & $\begin{array}{l}\geq 2 \text { hours } \\
<2 \text { hours }\end{array}$ & $\begin{array}{l}271 \\
197\end{array}$ & $\begin{array}{l}71 \\
50\end{array}$ & $\begin{array}{l}26.2 \\
25.4\end{array}$ & $0.31^{*}$ & 0.13 & 0.76 \\
\hline $\begin{array}{l}\text { The back bent at an angle of over } 45^{\circ} \text { without supportive } \\
\text { equipment for a prolonged duration }\end{array}$ & $\begin{array}{l}\geq 2 \text { hours } \\
<2 \text { hours }\end{array}$ & $\begin{array}{l}242 \\
226\end{array}$ & $\begin{array}{l}63 \\
58\end{array}$ & $\begin{array}{l}26.0 \\
25.7\end{array}$ & $0.40^{*}$ & 0.18 & 0.92 \\
\hline Medial rotation while walking & $\begin{array}{l}\geq 2 \text { hours } \\
<2 \text { hours }\end{array}$ & $\begin{array}{l}229 \\
239\end{array}$ & $\begin{array}{l}76 \\
45\end{array}$ & $\begin{array}{l}33.2 \\
18.8\end{array}$ & $3.01^{\star *}$ & 1.42 & 6.36 \\
\hline Carrying $>5 \mathrm{~kg}$ with one hand & $\begin{array}{l}\geq 2 \text { hours } \\
<2 \text { hours }\end{array}$ & $\begin{array}{l}114 \\
354\end{array}$ & $\begin{array}{l}39 \\
82\end{array}$ & $\begin{array}{l}34.2 \\
23.2\end{array}$ & $2.94^{*}$ & 1.15 & 7.48 \\
\hline \multicolumn{8}{|l|}{ Experience of psychological stress at work } \\
\hline Level of anxiety and frustration during the last week & $\begin{array}{l}\text { High anxiety } \\
\text { Acceptable }\end{array}$ & $\begin{array}{l}158 \\
310\end{array}$ & $\begin{array}{l}85 \\
36\end{array}$ & $\begin{array}{l}53.8 \\
11.6\end{array}$ & $3.31^{\star \star}$ & 1.46 & 7.52 \\
\hline Level of stress during the last week & $\begin{array}{l}\text { Highly discomfort } \\
\text { Acceptable }\end{array}$ & $\begin{array}{l}162 \\
306\end{array}$ & $\begin{array}{l}90 \\
31\end{array}$ & $\begin{array}{l}55.6 \\
10.1\end{array}$ & $7.14^{\star *}$ & 3.14 & 16.24 \\
\hline Level of satisfaction about work conditions during the last week & $\begin{array}{l}\text { Unsatisfied } \\
\text { Acceptable }\end{array}$ & $\begin{array}{l}76 \\
392\end{array}$ & $\begin{array}{l}44 \\
77\end{array}$ & $\begin{array}{l}57.9 \\
19.6\end{array}$ & $6.37^{* *}$ & 3.07 & 13.21 \\
\hline
\end{tabular}

hand raised above the head or elbow above the shoulder, the back bent at an angle of over $30^{\circ}$ without supportive equipment for a prolonged duration, squatting, kneeling, thoracolumbar flexion, lifting $>5 \mathrm{~kg}$ more than twice per minute, lifting $>37.5 \mathrm{~kg}$ once/day or $>27.5 \mathrm{~kg} 10$ times/day, lifting $>13.5 \mathrm{~kg}$ from the height of above the shoulder, below the knee or the distance of one arm more than 25 times $/ \mathrm{day}$, exposure to threat of psychological violence, and exposure to threat of physical violence.

upper limbs [19], [36], and shoulders [9], [20], [22], [35]. Further, continuous exposure to a variety of poor postures might trigger the onset of musculoskeletal pain at multi-body sites. Although more body sites with MSDs indicate the higher impact of this health problem, only a few studies report the prevalence of co-occurring pain among workers. The prevalence of multisite MSDs among WCs in this study (60.5\%) was higher than those of general working occupation (34\%) [10] and seafood processing workers (42.2\%) [11]. The significant proportion of WCs with long-term pain and of WCs with multisite MSDs emphasizes the importance of prompt measures to improve current working conditions.

\section{MSDs}

\section{Factors related to the risk of persistent}

The previous studies have reported that different gender [5], [8], [22] and age groups [6] among workers have varying influences for acquiring MSDs and these results are comparable to the findings of our study. Accordingly, being a female is often described as a "risk factor" for MSDs because of the difference in physical strength of the musculoskeletal system between men and women [29]; the negative impact of the same physical labor is generally greater on females than males, therefore higher prevalence of MSDs among women compared to men [22]. Further, a higher prevalence of MSDs among older workers or workers with longer work experience was observed because of the long-term exposure to occupational hazards [9], [13], [21], [29]. These results imply the need for mechanical support at work for female WCs and to older workers to prevent the risk of chronic MSDs and to reduce any compensated cost due to MSDs.
The results of this study regarding work organization, particularly on work shifts, were not as predicted because, among the work shifts, the night shift (Shift 3) had the most strenuous work, but lower risk of persistent pain was observed $(\mathrm{OR}=2.35, \mathrm{Cl}=0.26-0.92)$. At night, $\mathrm{WCs}$ are exposed to a higher level of psychological stress due to sleep deprivation, harsher climatic conditions (e.g., too wet or too cold), and fatigue. Moreover, the work shift only ends when all the garbage of the city have been collected and transported to the processing plant. Hence, sometimes work hour exceeds the regulation of 8 hours per shift. One probable explanation of the obtained results is that those WCs with existing musculoskeletal problems might be scheduled to the day shift before the study period since their physical health conditions were not suitable for the night shift. Therefore, further study on the association between work shift and the risk of persistent MSDs among WCs should be conducted to address the identified issue.

No significant association was observed between the risk of persistent MSDs and exposure to physical work environments such as sunlight, heat, coldness, and wetness. This result did not agree with the findings of another study. Magnavita et al. [26], in their study on hospital workers, reported that exposure to temperature and light $(\mathrm{OR}=1.92$ and 1.68, respectively) increased the risk of MSDs in the upper limbs and that temperature could also elevate the risk of MSDs in the lower back (OR = 1.31). In contrary, extended duration of carrying out the task in poor work postures (e.g., the neck/back bent for a prolonged time at an angle of over $45^{\circ}$ without supportive equipment, medial rotation while walking and carrying $>5 \mathrm{~kg}$ with 
one hand) elevated the risk of persistent MSDs in the WCs and this result agreed with published studies that reported an association between the increased risk of MSDs and poor working postures, quick motion, and continuous bending or twisting while carrying or lifting heavy objects [4], [8], [9], [37].

Psychological stress, anxiety, and job satisfaction experienced by WCs contributed to the risk of persistent MSDs since mental stress diverts resources spent on attention and can lead to fatigue and injury [4], [9], [26]. A study in Korea reported a significantly higher prevalence of depression and anxiety among workers with MSDs compared to those who did not have MSDs [38]. It is increasingly evident that addressing psychological factors impacting workers is crucial to prevent the development of persistent musculoskeletal pain.

\section{Limitations of this study}

Several limitations of this study have been identified. First, the heterogeneity in definition and symptom of MSD [2], the duration of reported persistent musculoskeletal pain [17], and the scarcity of evidence on persistent MSD among WCs in literature are recognized. Therefore, the discussion of this paper was limited to published studies with similarity in a certain aspect of the study design. Second, the application of self-reported health conditions and work conditions could create a certain level of bias on the prevalence of MSDs and risk of persistent pain among the investigated participants. It was not possible to determine the condition of persistent pain without a proper medical diagnosis, thus this paper only aimed to provide the relative risk of persistent MSDs with a screening purpose. Third, it was not possible to create the causal relationship between demographic and work conditions and the risk of persistent MSD with the cross-sectional study design of this paper. In addition, the applicability of the study results is limited to companies with similar work conditions. Hence, future studies should consider more robust study design such as cohort or randomized control trial to evaluate the impact of work conditions on MSDs among WCs in particular and different groups of occupation in general. Future studies should also include participants from different environment and sanitation companies for the results to be generalized to all WCs in Vietnam. However, this is the first paper to report the risk of persistent MSDs among WCs in Vietnam, using the ÖMPQ.

\section{Conclusions}

This study showed that the prevalence of MSDs, as well as multiple site MSDs (at least two sites), among WCs was high. The lower back was found to be the most affected site followed by the neck and shoulders. Workers with a higher risk of persistent MSDs were female, older, and worked more than 8 hours per shift. Work factors associated with persistent MSDs included poor postures, dissatisfaction with work, and the incidence of stress or anxiety a week before the survey. The high percentage of MSDs and the presence of factors related to a higher risk of persistent MSDs such as poor work postures and work-related psychological stress imply the need of mechanical and social support at work to prevent the development of chronic musculoskeletal pain. Automation of operation and use of different machinery on the job to aid in several work tasks such as lifting/carrying heavy objects or sweeping the street to replace the current manual operation would be beneficial. Social support, on the other hand, may include implementation of a better reward system to motivate workers, development of a coworker support system to assist and encourage one another, provision of adequate personal protective equipment, and timely provision of medical treatment for occupational injuries and other health problems.

\section{Availability of data and materials}

Additional data and materials are available on request to the corresponding author.

\section{Acknowledgments}

The authors would like to express our gratitude to the research team of the Hanoi University of Public Health for conducting the survey. We would also like to acknowledge the URENCO management board and the WCs for participating in the survey.

\section{References}

1. James SL, Abate D, Abate $\mathrm{KH}$, Abay SM, Abbafati C, Abbasi N, et al. Global, regional, and national incidence, prevalence, and years lived with disability for 354 diseases and injuries for 195 countries and territories, 1990-2017: A systematic analysis for the global burden of disease study 2017. Lancet. 2018;392(10159):1789-858. https://doi.org/10.341 0/f.731220250.793569875

PMid:30496104

2. Blyth FM, Briggs AM, Schneider $\mathrm{CH}$, Hoy DG, March LM. The global burden of musculoskeletal pain-where to from here? Am J Public Health. 2019;109(1):35-40. https://doi.org/10.2105/ ajph.2018.304747

PMid:30495997 
3. Malmberg-Ceder K, Haanpää $M$, Korhonen $P$, Kautiainen $H$. Relationship of musculoskeletal pain and well-being at workdoes pain matter? Scand J Pain. 2017;15:38-43. https://doi. org/10.1016/j.sjpain.2016.11.018

PMid:28850343

4. Korhan O, Memon AA. Work-Related Musculoskeletal Disorders. London: InTech Open; 2019.

5. Park J, Kim, Y, Han, B. Work sectors with high risk for workrelated musculoskeletal disorders in korean men and women. Saf Health Work. 2018;9(1):75-8. https://doi.org/10.1016/j. shaw.2017.06.005

PMid:30363078

6. Fulmer S, Buchholz B, Scribani M, Jenkins P. Musculoskeletal disorders in Northeast Lobstermen. Saf Health Work. 2017;8(3):282-9. https://doi.org/10.1016/j.shaw.2016.12.004 PMid:28951805

7. Kaka B, Idowu OA, Fawole HO, Adeniyi AF, Ogwumike OO, Toryila MT. An analysis of work-related musculoskeletal disorders among butchers in Kano Metropolis, Nigeria. Saf Health Work. 2016;7(3):218-24. https://doi.org/10.1016/j.shaw.2016.01.001 PMid:27630791

8. Karimi N, Moghimbeigi A, Motamedzade M, Roshanaei G. Evaluation of related risk factors in number of musculoskeletal disorders among carpet weavers in Iran. Saf Health Work. 2016;7(4):322-5. https://doi.org/10.1016/j.shaw.2016.04.004 PMid:27924235

9. Ziaei M, Choobineh A, Abdoli-Eramaki M, Ghaem H. Individual, physical, and organizational risk factors for musculoskeletal disorders among municipality solid waste collectors in Shiraz, Iran. Ind Health. 2018;56(4):308-19. https://doi.org/10.2486/ indhealth.2018-0011

PMid:29503392

10. Miranda $H$, Kaila-Kangas $L$, Heliövaara $M$, Leino-Arjas $P$, Haukka E, Liira J, et al. Musculoskeletal pain at multiple sites and its effects on work ability in a general working population. Occup Environ Med. 2010;67(7):449-55. https://doi.org/10.1136/ oem.2009.048249 PMid: 19889646

11. Tran TTT, Pham TC, Nguyen QT. After-shift musculoskeletal disorder symptoms in female workers and work-related factors: A cross-sectional study in a seafood processing factory in Vietnam. AIMS Public Health. 2016;3(4):733-49. https://doi. org/10.3934/publichealth.2016.4.733

PMid:29546192

12. Dunstan DA, Covic T, Tyson GA, Lennie IG. Does the orebro musculoskeletal pain questionnaire predict outcomes following a work-related compensable injury? Int J Rehabil Res. 2005;28(4):369-70. https://doi. org/10.1097/00004356-200512000-00012 PMid: 16319565

13. Maher CG, Grotle, M. Evaluation of the predictive validity of the orebro musculoskeletal pain screening questionnaire. Clin J Pain. 2009;25(8):666-70. https://doi.org/10.1097/ ajp.0b013e3181a08732 PMid:19920715

14. Hockings R, McAuley J, Maher C. A systematic review of the predictive ability of the orebro musculoskeletal pain questionnaire. Spine (Phila Pa 1976). 2008;33(15):E494-500. https://doi.org/10.1097/brs.0b013e31817ba3bb PMid: 18594447

15. Gabel C, bullet G, Melloh M, Michael b, Yelland M, Burkett B, et al. Predictive ability of a modified orebro musculoskeletal pain questionnaire in an acute/subacute low back pain working population. Eur Spine J. 2011;20(3):449-57.https://doi. org/10.1007/s00586-010-1509-4

PMid:20632045
16. Linton S, Boersma K. Early identification of patients at risk of developing a persistent back problem: The predictive validity of the örebro musculoskeletal pain questionnaire. Clin J Pain. 2003;19(2):80-6. https://doi. org/10.1097/00002508-200303000-00002

PMid: 12616177

17. Miranda VS, deCarvalho VB, Machado LA, Dias JM. Prevalence of chronic musculoskeletal disorders in elderly Brazilians: A systematic review of the literature. BMC Musculoskelet Disord. 2012;13(1):82. https://doi.org/10.1186/1471-2474-13-82 PMid:22642899

18. Ordóñez-Hernández C, Contreras-Estrada MI, SolteroAvelar R. Working women with chronic musculoskeletal pain: A case series. Cad Saude Publica. 2015;31(10):2223-33. https:// doi.org/10.1590/0102-311x00176514 PMid:26735388

19. Norman ID. Neck, wrist and back pain among solid waste collectors: Case study of a ghanaian waste management company. Int J Environ Health Eng. 2013;6(1):59-66. https://doi. org/10.2174/1874944501306010059

20. Sukadarin E, Fac O, Nfm S. Musculoskeletal disorder among municipal solid waste collectors. Asia Pac Environ Occup Health J. 2017;3(1):28-32.

21. Abou-EIWafa H, El Bestar S, El-Gilany AH, El-Toraby E. Musculoskeletal disorders among municipal solid waste collectors in Mansoura, Egypt: A cross-sectional study. Occup Environ Med. 2012;2:e001338. https://doi.org/10.1136/ bmjopen-2012-001338

22. Reddy EM, Yasobant S. Musculoskeletal disorders among municipal solid waste workers in India: A cross-sectional risk assessment. J Family Med Prim Care. 2015;4(4):519-24. https:// doi.org/10.4103/2249-4863.174270

PMid:26985409

23. Jayakrishnan T, Jeeja MC, Bhaskar R. Occupational health problems of municipal solid waste management workers in India. Int J Environ Health Eng. 2013;2(1):42. https://doi. org/10.4103/2277-9183.122430

24. Çakıt E. Assessment of the physical demands of waste collection tasks. Glob NEST J. 2015;17(10):426-38.

25. Zolnikov T, Silva RC, Tuesta AA, Marques CP, Resende V, Cruvinel N. Ineffective waste site closures in Brazil: A systematic review on continuing health conditions and occupational hazards of waste collectors. Waste Manag. 2018;80:26-39. https://doi. org/10.1016/j.wasman.2018.08.047

PMid:30455007

26. Magnavita N, Elovainio M, De Nardis I, Heponiemi T. Environmental discomfort and musculoskeletal disorders. Occup Med (Lond). 2011;61(3):196-201. https://doi.org/10.1093/ occmed/kqr024 PMid:21525071

27. Ziaei M, Choobineh A, Abdoli-Eramaki M, Ghaem H, Jaberi O. Psychological and physical job demands, decision latitude, and work-related social support among Iranian waste collectors. Waste Manag. 2019;95:377-87. https://doi.org/10.1016/j. wasman.2019.06.031

PMid:31351624

28. Menzel NN. Psychosocial factors in musculoskeletal disorders. Crit Care Nurs Clin North Am. 2007;19(2):145-53.

PMid: 17512470

29. Roquelaure $Y$, Ha C, Leclerc A, Touranchet A, Sauteron M, Melchior M, et al. Epidemiologic surveillance of upper-extremity musculoskeletal disorders in the working population. Arthritis Rheum. 2006;55(5):765-78. https://doi.org/10.1002/art.22222 PMid:17013824

30. Luong ND, Thanh BX, Hung N. Challenges for municipal 
solid waste management practices in Vietnam. Waste Tech. 2013;1(1):17-21. https://doi.org/10.12777/ wastech.1.1.2013.17-21

31. Terwee CB, Bot SD, de Boer MR, van der Windt DA, Knol DL, Dekker J, et al. Quality criteria were proposed for measurement properties of health status questionnaires. J Clin Epidemiol. 2007;60(1):34-42. https://doi.org/10.1016/j.jclinepi.2006.03.012 PMid:17161752

32. World Health Organization. Innovative Care for Chronic Conditions: Building Blocks for Action. Contract No: WHO/MNC/ $\mathrm{CCH} / 02.01$. Geneva: World Health Organization, Health NDaM; 2002.

33. Karran E, McAuley J, Traeger A, Hillier S, Grabherr L, Russek L, et al. Can screening instruments accurately determine poor outcome risk in adults with recent onset low back pain? A systematic review and meta-analysis. BMC Med. 2017;15:13. https://doi.org/10.1186/s12916-017-0814-8

PMid:28100231

34. Gabel C, Melloh M, Burkett B, Osborne J, Yelland M. The orebro musculoskeletal screening questionnaire: Validation of a modified primary care musculoskeletal screening tool in an acute work injured population. Man Ther. 2012;17(6):554-65. https://doi.org/10.1016/j.math.2012.05.014

PMid:22742989

35. Mehrdad R, Majlessi-Nasr M, Aminian O, Sharifian SA, Malekahmadi F. Musculoskeletal disorders among municipal solid waste workers. Acta Med Iran. 2008;46(3):233-8.

36. Hyang KL, Myong JP, Eun-Hee J, Hye-Sun J, Jung-Wan K. Ergonomic workload evaluation and musculo-skeletal symptomatic features of street cleaners. Ergon Soc Korea. 2007;26(4):147-52. https://doi.org/10.5143/jesk.2007.26.4.147

37. Camada IM, Pataro SM, Fernandes RC. Heavy physical work under time pressure: The garbage collection service-a case study. Work 2012;41 Suppl 1:462-9. https://doi.org/10.3233/ wor-2012-0197-462

PMid:22316767

38. Baek JH, Kim YS, Yi KH. Relationship between comorbid health problems and musculoskeletal disorders resulting in musculoskeletal complaints and musculoskeletal sickness absence among employees in Korea. Saf Health Work. 2015;6(2):128-33. https://doi.org/10.1016/j.shaw.2015.03.002

PMid:26106512 


\section{Appendix 1: Research questionnaires}

The situation of musculoskeletal disorders and related factors among Hanoi urban environment workers in 2017.

\begin{tabular}{|c|c|c|}
\hline Code & Questions & Response \\
\hline \multicolumn{3}{|c|}{ A. General information about the waste collectors } \\
\hline A1 & Year of birth (calendar) & Year: ........... \\
\hline \multirow[t]{2}{*}{ A2 } & Sex & 1. Male \\
\hline & & 2. Female \\
\hline \multirow[t]{6}{*}{ A3 } & Education level & 1. Primary school \\
\hline & & 2. High school \\
\hline & & 3. Senior high school \\
\hline & & 4. Vocational school \\
\hline & & 5. College and above \\
\hline & & 6. Other (state):..................... \\
\hline A4 & $\begin{array}{l}\text { How old were you when you started working at } \\
\text { your current position? }\end{array}$ & .......... years old \\
\hline \multicolumn{3}{|c|}{ B. Working conditions } \\
\hline \multicolumn{3}{|c|}{ Work organization } \\
\hline B1 & $\begin{array}{l}\text { On average, how many hours do you work per } \\
\text { shift? }\end{array}$ & $\ldots \ldots \ldots \ldots \ldots \ldots . . . . . .1$ hours \\
\hline \multirow[t]{4}{*}{ B2 } & In the past 3 months, what was your assignment? & 1. Shift 1 \\
\hline & & 2. Shift 2 \\
\hline & & 3. Shift 3 \\
\hline & & 4. Frequently change \\
\hline \multicolumn{3}{|c|}{ Exposure to physical occupational hazards } \\
\hline B3 & $\begin{array}{l}\text { What is your level of exposure to hot working } \\
\text { environment? }\end{array}$ & $\begin{array}{l}\text { 1. Frequently } \\
\text { 2. Low/seasonal exposure } \\
\text { 3. No exposure }\end{array}$ \\
\hline B4 & $\begin{array}{l}\text { What is your level of exposure to sunlight at } \\
\text { work? }\end{array}$ & $\begin{array}{l}\text { 1. Frequently } \\
\text { 2. Low/seasonal exposure } \\
\text { 3. No exposure }\end{array}$ \\
\hline B5 & $\begin{array}{l}\text { What is your level of exposure to cold working } \\
\text { environment? }\end{array}$ & $\begin{array}{l}\text { 1. Frequently } \\
\text { 2. Low/seasonal exposure } \\
\text { 3. No exposure }\end{array}$ \\
\hline B6 & $\begin{array}{l}\text { What is your level of exposure to wet working } \\
\text { conditions? }\end{array}$ & $\begin{array}{l}\text { 1. Frequently } \\
\text { 2. Low/seasonal exposure } \\
\text { 3. No exposure }\end{array}$ \\
\hline \multicolumn{3}{|c|}{ Work postures (see the illustration) } \\
\hline \multirow[t]{5}{*}{ B7 } & In your shift, how many hours do you work in the & 1. $\geq 4 \mathrm{~h}$ \\
\hline & posture with the hand raised above the head or & 2. $\geq 3 \mathrm{~h}$ \\
\hline & elbow above the shoulder? & 3. $\geq 2 \mathrm{~h}$ \\
\hline & & 4. $<2 \mathrm{~h}$ \\
\hline & & 5. Not perform \\
\hline \multirow[t]{5}{*}{ B8 } & In your shift, how many hours do you work in & $1 . \geq 4 \mathrm{~h}$ \\
\hline & the posture with the neck bent for a prolonged & 2. $\geq 3 \mathrm{~h}$ \\
\hline & duration at an angle of over $45^{\circ}$ without & $3 . \geq 2 \mathrm{~h}$ \\
\hline & supportive equipment? & 4. $<2 \mathrm{~h}$ \\
\hline & & 5. Not perform \\
\hline \multirow[t]{5}{*}{ B9 } & In your shift, how many hours do you work in the & $1 . \geq 4 \mathrm{~h}$ \\
\hline & posture with the back bent at an angle of over & 2. $\geq 3 \mathrm{~h}$ \\
\hline & $30^{\circ}$ without supportive equipment for a prolonged & 3. $\geq 2 \mathrm{~h}$ \\
\hline & duration? & 4. $<2 \mathrm{~h}$ \\
\hline & & 5. Not perform \\
\hline \multirow[t]{5}{*}{ B10 } & In your shift, how many hours do you work in the & 1. $\geq 4 \mathrm{~h}$ \\
\hline & posture with the back bent at an angle of over & 2. $\geq 3 \mathrm{~h}$ \\
\hline & $45^{\circ}$ without supportive equipment for a prolonged & 3. $\geq 2 \mathrm{~h}$ \\
\hline & duration? & 4. $<2 \mathrm{~h}$ \\
\hline & & 5. Not perform \\
\hline \multirow[t]{5}{*}{ B11 } & In your shift, how many hours do you work in the & 1. $\geq 4 \mathrm{~h}$ \\
\hline & squatting posture? & 2. $\geq 3 \mathrm{~h}$ \\
\hline & & 3. $\geq 2 \mathrm{~h}$ \\
\hline & & 4. $<2 \mathrm{~h}$ \\
\hline & & 5. Not perform \\
\hline
\end{tabular}

\begin{tabular}{|c|c|c|}
\hline Code & Questions & Response \\
\hline \multicolumn{3}{|c|}{ B. Working conditions } \\
\hline \multicolumn{3}{|c|}{ Work organization } \\
\hline \multirow[t]{5}{*}{ B12 } & In your shift, how many hours do you work in the & 1. $\geq 4 \mathrm{~h}$ \\
\hline & kneeling posture? & 2. $\geq 3 \mathrm{~h}$ \\
\hline & & 3. $\geq 2 \mathrm{~h}$ \\
\hline & & 4. $<2 \mathrm{~h}$ \\
\hline & & 5. Not perform \\
\hline \multirow[t]{5}{*}{ B13 } & In your shift, how many hours do you work in the & 1. $\geq 4 \mathrm{~h}$ \\
\hline & posture of medial rotation while walking? & 2. $\geq 3 \mathrm{~h}$ \\
\hline & & 3. $\geq 2 \mathrm{~h}$ \\
\hline & & 4. $<2 \mathrm{~h}$ \\
\hline & & 5. Not perform \\
\hline \multirow[t]{5}{*}{ B14 } & In your shift, how many hours do you work in the & 1. $\geq 4 \mathrm{~h}$ \\
\hline & posture of thoracolumbar flexion? & 2. $\geq 3 \mathrm{~h}$ \\
\hline & & 3. $\geq 2 \mathrm{~h}$ \\
\hline & & 4. $<2 \mathrm{~h}$ \\
\hline & & 5. Not perform \\
\hline \multirow[t]{5}{*}{ B15 } & In your shift, how many hours do you have to & 1. $\geq 4 \mathrm{~h}$ \\
\hline & carry $>5 \mathrm{~kg}$ with one hand? & 2. $\geq 3 \mathrm{~h}$ \\
\hline & & 3. $\geq 2 \mathrm{~h}$ \\
\hline & & 4. $<2 \mathrm{~h}$ \\
\hline & & 5. Not perform \\
\hline \multirow[t]{5}{*}{ B16 } & In your shift, how many hours do you have to & 1. $\geq 4 \mathrm{~h}$ \\
\hline & frequently lift $>5 \mathrm{~kg}$ (more than twice per minute)? & 2. $\geq 3 \mathrm{~h}$ \\
\hline & & 3. $\geq 2 \mathrm{~h}$ \\
\hline & & 4. $<2 \mathrm{~h}$ \\
\hline & & 5. Not perform \\
\hline \multirow[t]{5}{*}{ B17 } & In your shift, how many hours do you have to lift & 1. $\geq 4 \mathrm{~h}$ \\
\hline & $>37.5 \mathrm{~kg}$ once $/$ day or $>27.5 \mathrm{~kg} 10$ times/day & 2. $\geq 3 \mathrm{~h}$ \\
\hline & & 3. $\geq 2 \mathrm{~h}$ \\
\hline & & 4. $<2 \mathrm{~h}$ \\
\hline & & 5. Not perform \\
\hline \multirow[t]{5}{*}{ B18 } & In your shift, how many hours do you have to lift & 1. $\geq 4 \mathrm{~h}$ \\
\hline & $>13.5 \mathrm{~kg}$ from the height of above the shoulder, & 2. $\geq 3 \mathrm{~h}$ \\
\hline & below the knee or the distance of one arm more & 3. $\geq 2 \mathrm{~h}$ \\
\hline & than 25 times/day? & 4. $<2 \mathrm{~h}$ \\
\hline & & 5. Not perform \\
\hline & Psychological stress & \\
\hline \multirow[t]{4}{*}{ B19 } & $\begin{array}{l}\text { What is your level of anxiety and frustration during } \\
\text { the last week? }\end{array}$ & $\begin{array}{l}\text { 1. Completely comfortable/ } \\
\text { not anxious }\end{array}$ \\
\hline & & $\begin{array}{l}\text { 2. Mid anxious but } \\
\text { acceptable }\end{array}$ \\
\hline & & 3. Anxious \\
\hline & & 4. Very anxious \\
\hline \multirow[t]{4}{*}{ B20 } & What is your level of stress during the last week? & $\begin{array}{l}\text { 1. Completely comfortable/ } \\
\text { not stressful }\end{array}$ \\
\hline & & $\begin{array}{l}\text { 2. Mid stressful but } \\
\text { acceptable }\end{array}$ \\
\hline & & 3. Stressful \\
\hline & & 4. Very stressful \\
\hline \multirow[t]{4}{*}{ B21 } & What is your level of satisfaction with work during & 1. Absolutely satisfied \\
\hline & the last week? & 2. Satisfied \\
\hline & & 3. Normal \\
\hline & & 4. Not satisfied \\
\hline \multirow[t]{3}{*}{ B22 } & What is your level of exposure to threat of & 1. Frequently \\
\hline & psychological violence? & 2. Occasionally \\
\hline & & 3. Never/no exposure \\
\hline \multirow[t]{3}{*}{ B23 } & What is your level of exposure to threat of & 1. Frequently \\
\hline & physical violence? & 2. Occasionally \\
\hline & & 3. Never/no exposure \\
\hline
\end{tabular}




\section{Illustration of Working Postures}

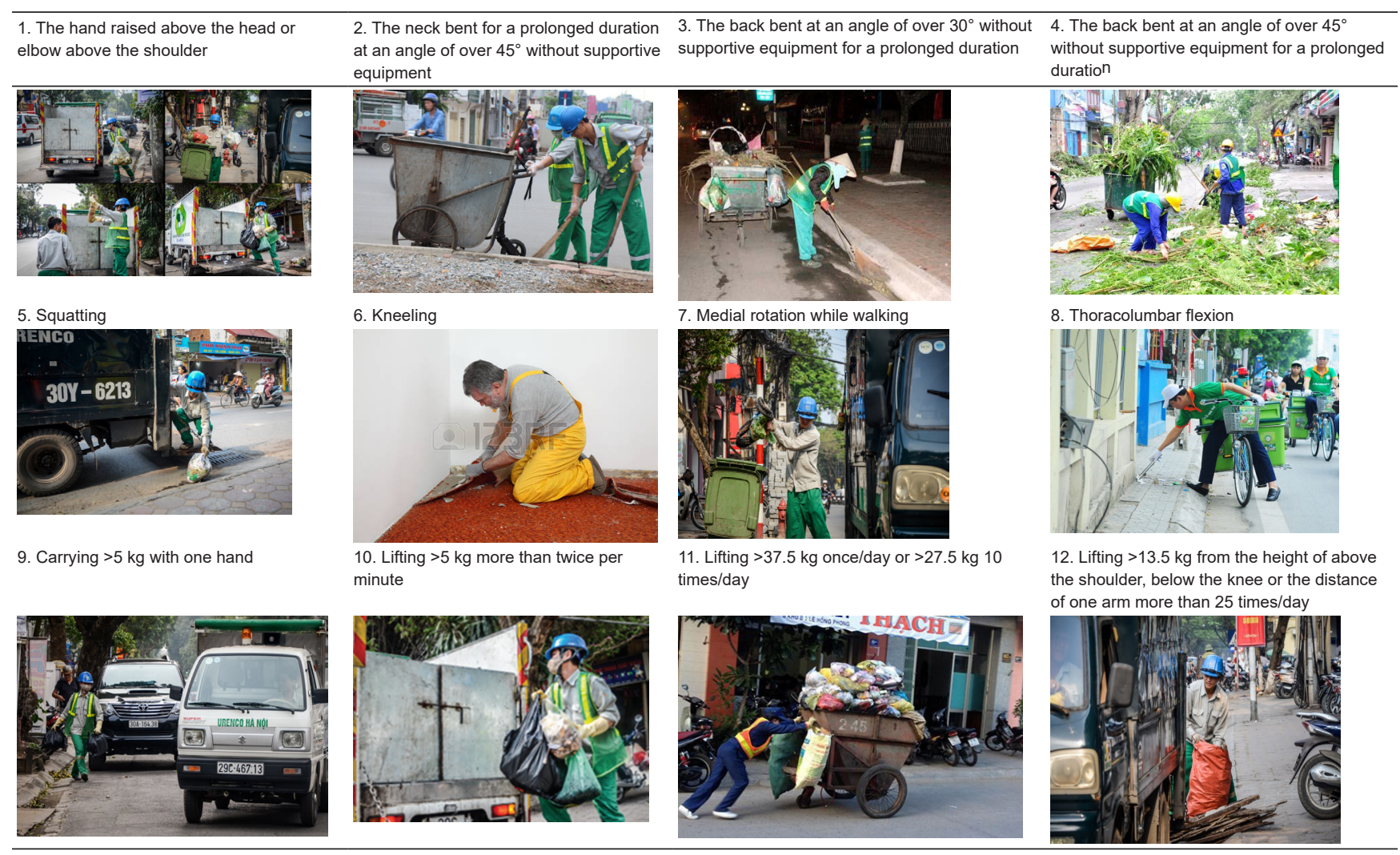


Örebro Musculoskeletal Pain Questionnaire (ÖMPQ) Linton and Boersma, 2003.

These questions and statements apply if you have aches or pains, such as back, shoulder, or neck pain. Please read and answer questions carefully. Do not take long to answer the questions, however, it is important that you answer every question. There is always a response for your particular situation.

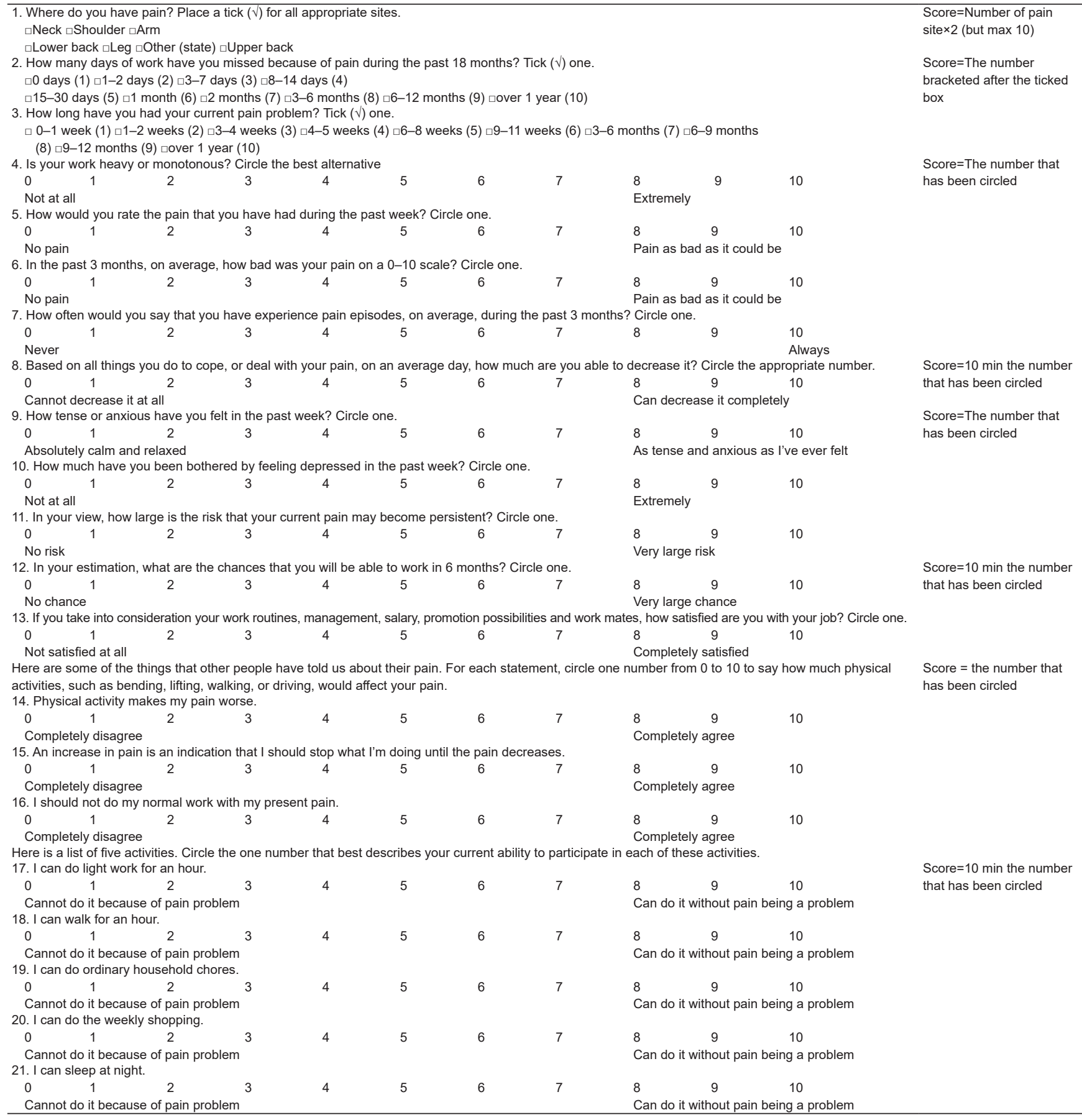

